\title{
Blikket blev rettet mod nord
}

\author{
af Emil Schrøder.
}

Den tyske kapitulation i maj 1945 blev indledningen til store omvæltninger i Sydslesvig. Tusinder og atter tusinder søgte kontakt til det danske. For mange blev det et varigt sindelagsskifte.

Emil Schrøder er en af de mange, som skiftede sindelag. Han er født i Slesvig i 1928 og voksede op $i$ en tysksindet familie. Hans erindringer tegner et billede af de vanskelige forhold i tiden lige efter krigen. Og de illustrerer nogle af de mange impulser, som kunne føre i dansk retning. Skridt for skridt blev Emil Schrøder dansk. I 1957 fik han dansk lærereksamen, og i 1965 dansk indfødsret.

"Man fødes ikke dansk, det er noget man bliver« Johannes $V$. Jensen

\section{Arbejdsdreng hos englænderne}

Et uforglemmeligt billede fra maj 1945, nærmest symbolsk: Ved indgangen til hotellet »Stadt Hamburg« i Slesvig står en engelsk vagtpost på den ene side og en tysk på den anden, begge bevæbnet. Den sidste stadig $100 \%$ soldat, ansigtet som mejslet i sten, tøjet korrekt, geværgrebet præcist. Den første derimod nærmest skødesløs, en civilist i uniform. Ubegribeligt, at England havde vundet krigen! Når man så de britiske soldater, der traskede gennem byen med hænderne i lommerne og med opslåede frakkekraver, forstod man det endnu mindre. Englændernes tilstedeværelse i deres khakifarvede battledress og deres fremmedartede køretøjer prægede fra nu af gadebilledet i Slesvig.

Jeg kunne ikke fortsætte med at læse til lærer på det tyske seminarium $\mathrm{i}$ Ratzeburg, for skolen var blevet lukket, og lærerne skulle afnazificeres. Derfor meldte jeg mig på arbejdsformidlingen. Sammen med nogle andre arbejdsløse blev jeg sendt til trælasten i Slesvig-bydelen Frederiksberg, hvor vi skulle flytte brædder. De fleste af os arbejdede dog kun til middag. Vi blev nemlig jaget væk af indehaveren, fordi vi havde smidt brædderne ned fra de store stabler $\mathbf{i}$ stedet for at række dem ned. Det resulterede $i$, at nogle af dem revnede eller blev snavsede. Desværre havde ingen gjort sig den ulejlighed at forklare os, hvordan vi skulle have båret os ad.

Nå, vi meldte os igen på arbejdsformidlingen og blev denne gang sendt til "Friheden« på Holmen, et kaserneanlæg for marineflyvere i nazitiden. R.A.F. (Royal Air Force) havde nu overtaget den. I dag er området kaserne for Bun- 


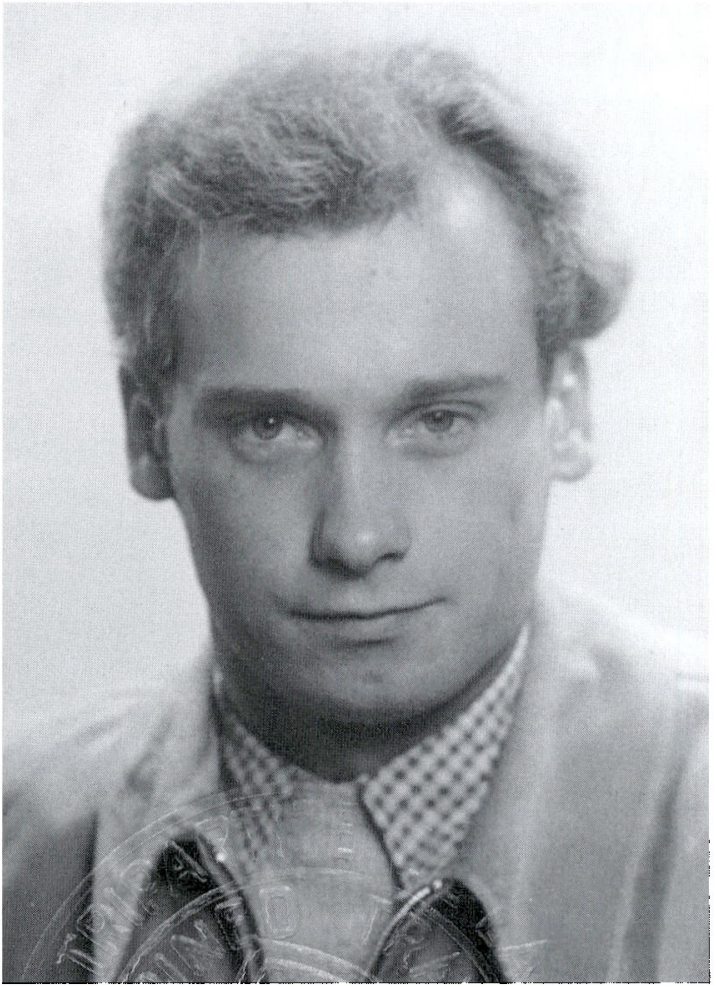

Emil Schroder. Pasfoto 1950. $A D C B$ personarkiv $P 318$.

deswehr. Vores arbejde bestod i at rydde op, og det var også tiltrængt. Ved fyraftenstid passerede vi vagtposten; men da det viste sig, at kontrollen foregik noget lemfældigt, lykkedes det af og til at smugle forskelligt med ud, bl.a. corned beef, som jeg ikke kendte, men som smagte ganske fortrinligt.

Efter otte dages forløb på »Friheden« fik jeg en ny arbejdsplads hos besættelsesmagten. Organisationen hed »Salvage«. Mellem Husumerbaum og Karpfenteich lå et teglværk. Det skulle indrettes til depot for materiel fra den tyske værnemagt. Og efterhånden som flere og flere englændere blev sendt hjem, blev ligeledes deres tilbageblevne materiel opbevaret her.

I de første uger kørte vi rundt til grusgravene i Slesvigs omegn for at hente kampesten. De blev tippet ned i ringgraven, hvor ellers stenene blev brændt. Langsomt, men sikkert blev den fyldt op. På den måde blev der skabt en kæmpemæssig hal, hvor tekstiler m.m. blev sorteret og opbevaret. Ligeledes blev tørreskurene taget $\mathrm{i}$ brug som oplagringsplads. Bulldozere og gummigeder planerede terrænet, også den forhenværende lergrav. For første gang i mit liv så jeg disse grådige maskiner æde sig gennem landskabet, der snart blev fuld- 
stændigt forvandlet, og resultatet var store arealer, hvor der blev stablet alskens sager op lige fra æsker med aluminiumsnitter til motorer.

Da vi ville "organisere« nogle trækasser, truede en engelsk løjtnant os med sin pistol. De blev jo alligevel ødelagt, og vi kunne godt have brugt dem, da de var yderst velegnede til kaninbure. Vi var nu desværre nødt til at droppe sagen; men der var meget andet, vi kunne bruge og nemt tage med hjem, uden at nogen ville opdage det, f.eks. halstørklæder og strømper, der omgående blev trevlet op. Af garnet, som helst blev farvet med det samme, blev der strikket nye beklædningsgenstande.

I begyndelsen optrådte englænderne som herskere over for os, der kun havde at adlyde, for vi var »fucking Germans«. De måtte kun tale med os i det omfang, arbejdet krævede det.

Utvivlsomt frygtede de tyskerne endnu, hvad følgende lille episode måske kan belyse: Befolkningen var tvunget til at aflevere enhver form for skyde- og stikvåben. Selv knive over en vis længde faldt ind under forbudet. I en grusgrav i nærheden blev alt smadret, lige fra de dejligste antikviteter til de mest moderne håndvåben fra Den anden Verdenskrig. Vi tog fat $\mathrm{i}$ bøsseløbet, slog skæftet af al kraft mod en stor sten og smed det ødelagte våben over $\mathrm{i}$ en bunke. Den vagthavende soldat, selvfølgelig bevæbnet, afbrød vredt og kommanderede, at det skulle gøres grundigere, for disse "fucking Germans« var så satans dygtige, at de sagtens kunne få geværerne til at skyde igen. Så hamrede vi løs mod stenen en ekstra gang. Desværre måtte vi ikke forinden undersøge magasinerne for at se, om der endnu befandt sig patroner $i$ dem. Det var af hensyn til soldatens sikkerhed. Det blev dog farligt, også for den vagthavende, da vi hældte benzin over det hele og satte ild til. Da knaldede og piftede det nok så lystigt.

Bittert var det for os at se soldaterne spise. Sultne stod vi i nogen afstand og betragtede den dejlige mad, som blev serveret i så rigelig mængde, at de ikke kunne spise op; men vi fik ikke en bid, og alle levningerne blev smidt i affaldstønden til grisefoder. De måtte vistnok ikke give os noget af maden.

Med tiden ændredes forholdet, først selvfølgelig for pigerne, der hjalp til i køkkenet. Iblandt dem var der en tøs fra vores kvarter. I en af middagspauserne lagde vi mærke til noget mistænkeligt. Vi så hende og en af chaufførerne gå hen til en lastbil med presenning. Hun kravlede op bag i den, mens han startede motoren; men i stedet for at køre bort bakkede han mod et af tørreskurene. Så standsede han motoren, steg ud, gik bag om bilen og klatrede op til hende. Straks forstod vi, hvad der skulle ske og listede ind $\mathrm{i}$ bygningen $\mathrm{og}$ derfra hen til skuret. Den øverste del af muren bestod af vandrette brædder, der var skråtstillede, sådan at luften frit kunne komme ind. Vi havde med andre ord den bedst tænkelige »balkonplads« og kunne iagttage samlejet. Til 
sidst gav han hende forskellige levnedsmidler og cigaretter, som han tog frem fra det ene hjørne. Nu skyndte vi os ned og nåede tids nok frem til at se ham klatre ned, og da han vendte sig om og fik øje på os, var han straks klar over, at vi vidste, hvad han havde forlystet sig med i bilen og blev blussende rød. Vi sagde ikke et ord til ham; men da tøsen viste sig, hånede vi hende.

Dagen efter kørte en arbejdskammerat og jeg med ham til Holsten for at hente gasflasker. Undervejs tog han nogle fotografier frem af sin kone og sine børn. Han holdt oprigtigt af dem og ville gerne have været hjemme hos dem; men den forbandede krig var skyld $i$ det hele, og det kunne han nok have ret i.

Som regel hørte jeg til det hold, der var tildelt chaufførerne, og efterhånden kom vi på en mere fortrolig fod med dem og fandt især hurtigt ud af, hvem der var gavmild, og hvem der var nærig. Det var bl.a. vigtigt, når vi skulle vaske deres "cars«. Først blev der brugt rigeligt med vand, og så fik lakken en omgang med dieselolie, så bilerne kom til at skinne og se ud som ny. Når »driveren« var tilfreds med resultatet, kunne man være heldig at få nogle cigaretter. Det samme kunne ske undervejs i bilen, når han tog sig en smøg, så fik man gerne en med. Første gang sagde jeg, at jeg var ikke-ryger, og så puttede han pakken i lommen igen. Næste gang sagde jeg dog »ja tak«, for cigaretter var meget værd dengang som betalingsmiddel; men desværre krævede han cigaretten tændt, og så var der ikke andet at gøre end at ryge den. Nogle gange kunne jeg dog se mit snit til at slukke den efter at have røget lidt for så at tage den med hjem til min far, der var vendt hjem fra krigen. Af og til kunne jeg desuden nå at samle chaufførens skod op. Det var iøvrigt blevet et ganske dagligdags syn at se folk bukke sig efter cigaretskod $i$ rendestenen.

Arbejderne på denne arbejdsplads kom fra alle mulige samfundslag, der på grund af tidens ugunst tilfældigt var havnet her. Der var gamle og unge, hjemmehørende og flygtninge. I pauserne kunne man således høre en ældre skuespiller fra Königsberg deklamere af Goethes og Schillers dramaer, mens en bleg splejs andægtigt lyttede til. Eller man kunne se en fortvivlet kunstmaler gå fra den ene til den anden og spørge, om man ikke havde en farvelade liggende derhjemme. Jeg gav ham min.

I timevis kunne vi stå i en lang række og kaste benzindunke til hinanden, hvorved man kom til at dreje hovedet fra den ene side til den anden. Som regel foregik det i en jævn rytme; men for sjovs skyld kunne tempoet pludselig blive sat op. Ganske vist faldt nogle af dunkene så på jorden; men de kunne altid blive samlet op senere. Det var vældig morsomt, dog kun til jeg fik en af dem i hovedet. Den ramte mig lige over øjet, og blodet strømmede ned. Nå, skidt med det, der fik jeg reddet mig en fridag.

I en længere periode hjalp jeg til hos snedkeren. Vi startede med at skrue 
kompashuse fra hinanden. De var lavet af det fineste mahognitræ. Arbejdet blev gjort meget omhyggeligt, for der måtte absolut ikke være skruer eller søm i træet, da det skulle høvles bagefter. Da vi havde tilstrækkelig mange brædder, kørte vi til et byggefirma ved domkirken, hvor de skulle køres gennem høvlemaskinen. Ejeren så rødt, for han frygtede med rette, at vi kom til at ødelægge hans kostbare maskine, og reservedele var det sikkert umuligt at få; men han turde ikke sige nej. Arbejdet skred frem uden problemer; men pludselig lød der et knald, og skaden var sket.

Snedkeren fremstillede nu møbler og småting til englænderne. På et tidspunkt blev dette arbejde dog afbrudt for at bygge et vagtskur og for at sætte en bom op. For at skåne vores egne klude var vi begyndt at tage engelsk uniform på. Jeg var således sergent i R.A.F. Ingen tog anstød af det, og vi syntes, det var vældig sjovt, når lastbilerne måtte standse foran bommen og vente, til vi kom ud for at give fri passage. Chaufførerne blev som regel siddende i deres biler; men en skønne dag steg en af dem ud og kom hen til mig, gjorde honnør og spurgte om noget. Jeg hilste igen og svarede på gebrokkent engelsk. Han studsede og må vel bagefter have klaget hos løjtnanten, og fra da af blev det os forbudt at gå i militærtøj.

Englænderne benyttede også en bygning ved rebslageriet, der lå i nærheden. Det blev depot for gamle melsække. Området blev ikke bevogtet, og det var let at komme ind i huset. Efter fyraften sneg vi os derind og gik i gang med at ryste sækkene, og det var forbløffende, hvor meget dejligt snehvidt hvedemel, der stadig befandt sig i dem. Min mor var mere end henrykt, for vi fik færre og færre rationeringsmærker, og nu kunne vi endelig få lidt mere at spise. Ganske vist kunne noget af melet være lidt muggent; men det gjorde ikke spor. Hver gang, vi hentede en ny portion, lagde vi mærke til et tysk automatisk gevær $\mathrm{i}$ en vinduesbænk. Det lod vi dog ligge.

\section{Vi slog os igennem}

I slutningen af november 1945 sluttede mit arbejde hos englænderne, og jeg var atter arbejdsløs.

Allerede inden min far var kommet hjem fra krigen, og onkel Heini fra Hamborg endnu boede hos os, tog vi ud i skoven med vores lille trækvogn, bevæbnet med økse og sav. Der gik vi i gang med at fælde et passende lille træ. Arbejdet foregik støt og roligt; men hele tiden lyttede vi og var parat til at stikke af, hvis vi skulle blive overrasket. Når træet faldt med et brag, gav det genlyd i hele skoven, og vi lyttede med tilbageholdt åndedræt og bankende hjerte. Derefter blev stammen og grenene skåret op i passende stykker, og med 
tungt læs asede vi hjemad. Hugsten foregik som regel tidligt om morgenen ved 4-tiden og helst $i$ diset vejr, for så var der ringe udsigt til, at vi mødte nogen. Vi hentede bl.a. en stor slank ask, der egnede sig fortrinligt som antennemast. Vi brugte cyklerne til transporten. Min onkel, der havde mistet sit ene ben på halvøen Krim, klarede alle strabadserne. Han havde en enestående udholdenhed og energi og var $\mathrm{i}$ besiddelse af en overraskende koldblodighed i modsætning til min far, der nærmest rystede i bukserne og fik ondt i hjertet og som mente, at dette var værre end forholdene under krigen. Selvfølgelig tog vi også kvas og tørre grene, der kunne fyres med i komfuret. Hvis der ikke lå nok på jorden, klatrede jeg op i træerne og savede døde grene af. Senere ryddede vi stubbene. Meget hurtigt lærte vi, at der var forskel på træer. Til at begynde med sled man med en bøgestub i flere timer og kunne ikke komme nogen vegne med den, for så til sidst at måtte opgive med en ed og så prøve ovre ved en granstub, som straks viste sig at være mere medgørlig. Nu kunne vi fint benytte de spidshakker, vi havde »fundet« i det nedlagte teglværk; men det var alligevel et hestearbejde at grave stubbene op, at køre dem hjem, at skære dem i passende længde og så at kløve dem med kilerne. Kroppen var tit badet $\mathrm{i}$ sved. Det var afgjort nemmere at »organisere« nogle af de nye jernbanesveller, der lå langs med skinnerne, og som var beregnet til udskiftning af de gamle.

Alle, der havde mulighed for det, skaffede sig brændsel på denne måde, forudsat at de ejede værktøj eller kunne låne noget. Men selv det bedste redskab blev hurtigt sløvt, og nu fik vi gavn af værktøjskassen, som vi havde fået fingre i i kapitulationsdagene. Heri lå file og et apparat til at lægge savtænder ud med. Naboerne henvendte sig snart til os for at få ordnet deres save. Der skulle betales med naturalier, helst kød, brød, tobak el.lign. Senere, da tørveproduktionen var kommet $\mathrm{i}$ gang, tiltuskede vi os adskillige læs af dette brændsel.

Selv om vi sandelig skaffede meget til huse, var det ofte alligevel ikke nok. Det kunne knibe med at få varmet køkkenet op, og i regelen blev der kun fyret dér. Komfuret stod midt i rummet, og flere meter lange kakkelovnsrør førte til skorstenen for at forhindre, at varmen forsvandt ud i den blå luft.

Mændene kunne aldrig få nok at ryge, og de, der havde have, dyrkede selv tobak. Vi tilplantede således næsten halvdelen af jorden med enten russisk bondetobak, der havde gule blomster og små ovale blade, eller med virginia, der blev større, og som havde lange, spidse blade og røde blomster. Bladene blev trukket på snor og hængt til tørre på loftet. Når de fik gule pletter, blev de taget ned, stablet og udsat for pres i nogle dage. Somme tider blev de forinden stænket med svedskesaft el.lign. Derefter gærede de tilpas og blev rullet sammen til store cigarer og skåret fint. Det skete med »brødmaskinen«, som vi konstruerede af en brødkniv. Det gik udmærket. Stænglerne blev taget 
fra og skåret for sig, for intet måtte gå til spilde, og på den måde fik vi en anselig portion tobak; men den skulle også række frem til næste års høst. Snart dukkede "gode« venner op med piber med stort pibehoved; og sådanne venner måtte nøjes med stænglerne.

Mine forældre blev meget glade, da mine søstre fortalte, at man kunne få cigaretter som betaling for at vaske for engelske soldater, der var stationeret på flyvepladsen Jagel knap $10 \mathrm{~km}$ fra vores bopæl. Denne lange strækning gik de herefter en gang om ugen. De fulgte jernbanesporet for at afkorte vejen og kom hjem med et stykke kærnesæbe og en stor bylt tøj. Det blev lagt $\mathrm{i}$ blød, og så blev der fyret op under gruekedlen, hvor tøjet blev kogt en times tid. Derefter skrubbede og gnubbede mor det på vaskebrættet. Så skyllede hun det flere gange og hængte det op på tørresnoren. Tøjet skulle derefter rulles eller stryges. Det blev tit en lang og hård arbejdsdag; men det var umagen værd, for cigaretterne kunne byttes til levnedsmidler. Vi kunne have fået mere mad, hvis ikke far havde røget en del af cigaretterne; men det var der ikke noget at gøre ved. Vi havde det dog afgjort bedre end i de familier, hvor manden tog af børnenes rationeringsmærker for at få tiltusket sig tobak.

Ugen efter afleverede pigerne det rene tøj og hentede nyt snavset. De blev ofte lovlig længe væk og kom måske først hjem efter mørkets frembrud, og så blev vi urolige for dem. Til slut nægtede de at gå mere, for soldaterne kunne blive lidt for nærgående; men min far tvang dem til at fortsætte, og så gik de grædende. Jeg tror, at de til sidst benyttede sig af en nødløgn og sagde, at soldaterne ikke længere ville have vasket, eller at de var blevet hjemsendt.

En af kammeraterne i gaden opholdt sig illegalt hos forældrene. Han havde tilhørt Waffen-SS, havde sidst været i Norditalien og var taget hjem for at undgå fangenskab. En skønne dag blev han hentet af det engelske militærpoliti og fløjet til en lejr i England. En pige, der var kæreste med en englænder, havde røbet ham. Han kom dog snart tilbage på grund af sin unge alder.

Hverdagen var stadig bestemt af kampen for det daglige brød, og jævnligt gik vi til en hesteslagter i den anden ende af byen, for der fik man dobbelt så meget kød for sine rationeringsmærker. Vi stod i kø i timevis, og ikke alle var så heldige, at de fik noget. Vi cyklede også til omegnens mejerier med vores mælkespande for at få lidt ekstra skummetmælk.

En af vore naboer var chauffør ved trælasten. Han havde mulighed for at smugle finérplader ud af lageret, og for tobak fik vi nogle af dem. Hele november og december 1946 fremstillede vi legetøj, som vi byttede mod levnedsmidler. Denne jul havde vi rigelig med mad.

Nogle gange har jeg i min fritid hjulpet en malermester med at hvidte lofter og male vægge. Som tak for hjælpen fik jeg et måltid mad, selv om de ikke havde nok selv. Der var en snes børn, og ved spisningen sad husfaderen for 
bordenden med en lang stok for at holde styr på hele flokken. Han smurte selv madderne, og det var sandelig et kunststykke, for ét æg skulle række til dem alle.

Det stod også sløjt til med beklædningen. Lige efter kapitulationen gik jeg iført min fars langskaftede SS-støvler og sorte spidsbukser og med hans grå hat. Alle dele var lidt for store. Senere fik jeg på en eller anden måde anskaffet noget andet. Jeg kan huske blå sømandsbukser med svaj og en hvid vindjakke. En frakke blev syet af gummieret lærred, som vi tilfældig fik fat i. Skoene havde træsåler eller var jernbeslåede. Vi reparerede dem normalt selv, og vi havde alt til formålet lige fra trefod til træpløkker.

Vi havde forøvrigt fået brev fra Erwin, en af mine klassekammerater fra seminariet, der engang havde tilbragt sin sommerferie hos os. Han opholdt sig $\mathrm{i}$ en fangelejr og kunne kun blive løsladt, hvis han kunne henvise til en adresse i en af besættelseszonerne. Hans forældre havde boet $i$ Vestpreussen (i dag en del af Polen), og han anede ikke, hvor de opholdt sig. Han spurgte derfor, om vi ville tage imod ham. Jeg fik mine forældre overtalt til det, selv om de ikke var begejstrede. Det lykkedes derefter at finde en læreplads til ham hos en snedker i vores bydel. Han boede hos os i et par år.

\section{I murerlære}

Kort efter at jeg var blevet arbejdsløs, kom der besked om, at alle ledige skulle give møde i salen i restaurant "Großer Baumhof«. Efter en lægeundersøgelse dér ville man blive sendt til kulminerne i Ruhrområdet. Det ville jeg meget nødig. Der fandtes kun én udvej: at få beskæftigelse med det samme! Min far arbejdede som murer $i$ et lille byggefirma, der kun bestod af ham selv og mesteren, der var en fjern slægtning til min mor. Han havde endnu aldrig haft en læredreng, men gik med til at tage mig. Med en skrivelse, der bekræftede den indgåede lærekontrakt, ilede jeg til mønstringen, hvor jeg fremviste den og omgående fik lov til at gå hjem igen.

Den 1.december 1945 begyndte min 3-årige uddannelse. Der fandtes så at sige ingen materialer, og $i$ dagevis sad jeg $i$ skuret og knuste hårde cementklumper med hammeren. Ellers brugte vi ler, og hvis vi var heldige, kalk og chamotteler. Det sidste bruges til at mure ildfaste sten med. Vi udførte kun småreparationer, og som regel drog vi af sted med en spand mørtel i den ene hånd $\mathrm{og}$ noget værktøj i den anden for at udbedre nogle huller i murværk. Hvis arbejdsstedet lå længere væk, benyttede vi enten cyklen eller kærren. Skulle der hvidtes et hus, repareres et tag, en skorsten eller tjæres et paptag, tog vi også en stige med. Desuden murede vi gruekedler op eller istandsatte dem. Jævnligt 


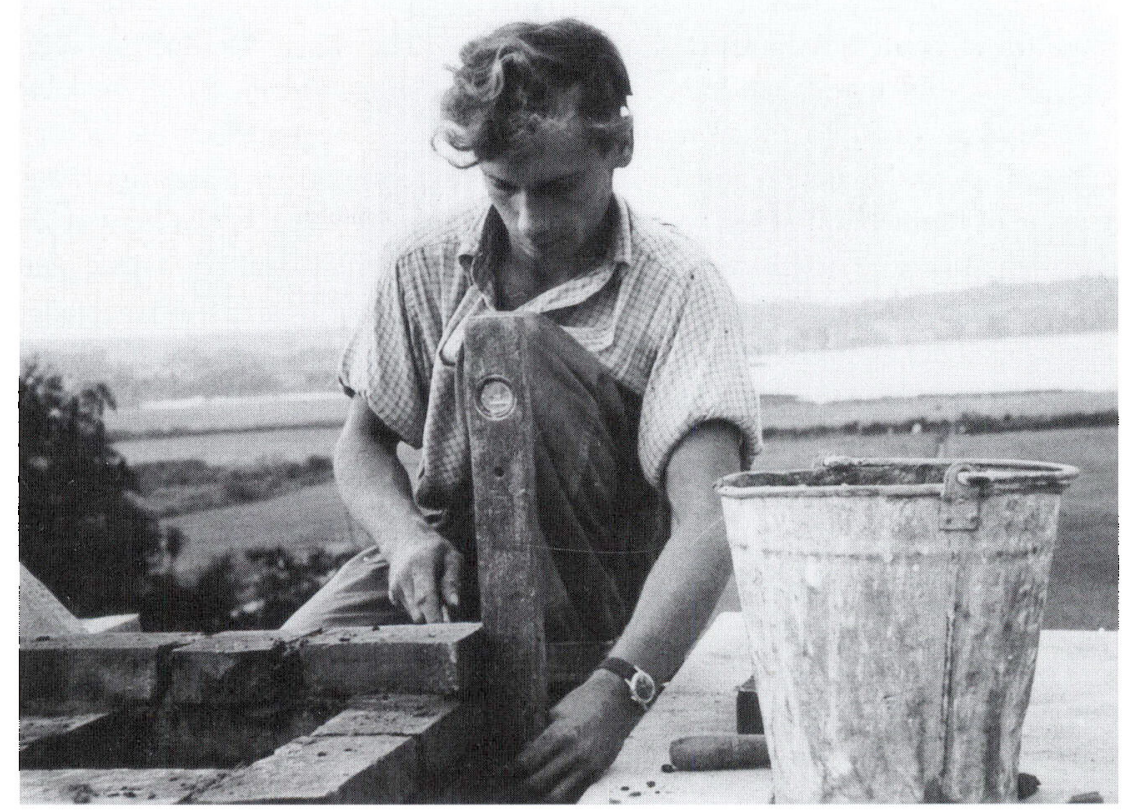

Emil Schroder murer en skorstenspibe på Gottorpskolen 1951. Foto i personarkiv P 318.

måtte jeg hen til en tjærepapfabrik og kravle ind $\mathrm{i}$ ovnene for at udbedre skader. Næsten ethvert hus havde fået tildelt flygtninge, og overalt manglede der ildsteder. I mange tilfælde var det umuligt at slutte dem til en skorsten; men så blev kakkelovnsrøret ført ud gennem et af vinduerne, der blev muret til.

Både mester og far arbejdede først og fremmest hos kunder, der kunne lokke med et eller andet. Men oftest kunne de kun give småting, for de havde ikke ret meget selv. Meget tit skaffede folk selv de materialer, der skulle bruges, for mesteren fik sjældent tildelt noget, og så kun i utilstrækkelige mængder.

Vi kunne godt lide at komme i et bageri, for dér fik vi »sort« brød. Bageriet arbejdede for englænderne og bagte derfor også kager, hvorfor der altid var noget kagesmuld på bordene.

Tanken om den daglige mad spillede en enorm rolle, og vi spiste alt, hvad vi kunne få fat i. Således husker jeg med taknemmelighed nabokonens dejlige vælling, kogt på sødmælk, for normalt fik vi kun skummetmælk. Vællingen var lidt sveden, og hendes børn var kræsne. I stedet for at smide maden væk, tilbød hun mig den, og gryden blev tømt med stort velbehag. Mesterens kone gav mig også lidt i ny og næ, f.eks. piskede hun saft og sukker sammen til en dejlig creme, der smagte vidunderligt. 
Da vi nærmede os høsten 1946, gik Erwin og jeg tit ud på »markvandring«, enten for at hente hestebønner, kartofler, kålroer eller korn. Det hændte selvfølgelig, at vi blev opdaget; men vi nåede altid at slippe væk i tide. Vi huskede hver gang at løbe $i$ en anden retning, end vi boede. I begyndelsen fik vi korn ved pænt at sanke aks på stubmarkerne; men det gav kun et magert udbytte, hvorfor vi fandt på at skære aksene af stråene på de ikke-høstede marker og sidenhen af negene. Hjemme gned vi kernerne ud, tørrede dem og malede dem i kaffemøllen. Af melet blev der sædvanligvis kogt grød, hvortil der serveredes "frugtsaft«, der bestod af vand og rød farve, tilsat sakkarin. Selvfølgelig fik vi bedre mad på festdage, hvor mor endog kunne sætte lagkage på bordet.

Desuden havde vi unge mulighed for at kunne fouragere $\mathrm{i}$ en nærliggende kolonihave, hvor der voksede de dejligste bær, æbler, pærer og blommer. Her kunne man uforstyrret plukke i ro og mag, for efter kl. 22 eller senere kl. 23, når udgangsforbudet trådte $\mathrm{i} \mathrm{kraft}$, holdt de voksne sig inden døre. Nogle fandt dog på at overnatte $i$ lysthusene.

Hver mandag gik jeg til undervisning på Teknisk skole. Mange i klassen var allerede fyldt 20 og var kun på grund af de vanskelige tider gået i murerlære. Efter afsluttet læretid ville de enten aflægge mesterprøven, læse til ingeniør eller arkitekt. Det var så afgjort en klasse med mange gode hoveder i.

I timerne blev der tegnet og regnet. Der kunne være meget koldt i klasseværelset om vinteren, derfor beholdt vi overtøjet på. Med længsel så vi hver gang frem til middagspausen, dagens lyspunkt, hvor vi som regel fik kakaovælling. På ekskursioner kravlede vi bl.a. rundt på domkirkens loft for at studere hvælvinger og tagkonstruktioner, eller vi aflagde besøg i »Præsidentklostret«, en stiftelse fra 1600-tallet. Da den første eksportmesse blev åbnet i Flensborg, kørte vi hen for at se på de mange interessante varer. Det føltes som et forvarsel om bedre tider.

Nogle måneder senere fik min far og jeg en herlig arbejdsplads i landsbyen Esprehm ved Hedeby, hvor vi opholdt os et kvart års tid. I begyndelsen boede vi hos en storbonde, der ejede en pragtfuld saksergård, og for ham byggede vi en transformator, lejligheder $\mathrm{i}$ to stalde, et lysthus og forskelligt andet. Her havde vi materialer nok, som han skaffede sig ved sortbørshandel. Således fik vi mursten, der stammede fra bombede huse fra Kiel. Lige inden vores afrejse blev gårdejeren dog meldt til politiet og arresteret for at have slagtet »sort«.

\section{Fritid og forlystelser}

I den tid, vi opholdt os der, var der polterabend i landsbyen. Alle unge samledes i en lo, hvor der allerede lå et sandt bjerg af gran og blomster, som man 
bandt guirlander af. Dertil benyttede man de lange reb, der ellers brugtes til at binde lossebommen fast med i høsttiden. De færdige guirlander blev bagefter hængt op i landsbyens gade, og derpå gik vi hen til brudgommens hjem med alskens skrammel og stablede det op foran døren. Det unge par kom så ud og bød på noget at drikke, og aftenen sluttede med dans til harmonikaens toner.

Selv efter, at vi havde afsluttet vores arbejde $\mathrm{i}$ landsbyen, opretholdt jeg kontakten med karlen. Vi mødtes næsten hver lørdag til dans på Hedeby Kro. Han havde tit noget at drikke med, selvfølgelig ulovligt brændt snaps, og også af den grund sværmede pigerne hurtigt om ham. Uventet kunne politiet dukke op, og så måtte karlene stille op på den ene langside og pigerne på den anden. Af og til lykkedes det dog nogle at springe ud af et vindue. Vi måtte nu fremvise vores legitimationsbevis, og alle under 18 år, især pigerne og gamle kendinge af politiet, blev taget med på politistationen.

Der fandtes dengang mange gode danseorkestre, der spillede den ene medrivende dans efter den anden. Mest begejstring vakte især de nyeste hit, men også gamle slagere, og musikanternes ildhu smittede af på de dansende. Selvfølgelig foretrak vi moderne rytmer. Af og til blev der arrangeret præmiedans, hvor der skulle danses vals, foxtrot og tango. Nu kunne vi vise, hvad vi havde lært i danseskolen. Men selv om jeg næsten altid deltog, vandt jeg aldrig noget. Der kunne også blive indlagt musikalsk underholdning. Trommeslageren eller trompetisten gav så et solonummer, og engang foredrog klaverspilleren følsomt ouverturen til »Digter og bonde« af Suppé.

I disse år har jeg set adskillige film. Det var ofte engelske film, der unægtelig havde et andet indhold end de tyske, jeg tidligere havde set. I timevis stod vi i kø for at få billetter. Det samme gjaldt også for teatret. Jeg gik især til lystspil og operetter, der i starten blev spillet i »Großer Baumhof «, hvad der var meget uheldigt for os, der boede i den anden ende af byen, for på grund af udgangsforbudet måtte vi gå før slutningen, og derfor så jeg f.eks. ikke sidste akt af "Jomfruburet«. Englænderne havde beslaglagt byens teater, som de kaldte "Dury Lane Theatre«. Det ligger mere centralt, og det hjalp, da det atter stod til rådighed for civilbefolkningen. Her så jeg for første gang en opera, det var "La Bohéme« af Puccini, som gjorde et stort indtryk på mig. Den betagende musik passede fint til den sørgelige handling. Dog kunne skuespillernes præstationer måske have været bedre; men det skyldtes måske kulden i salen, og de frøs vel lige som vi, der sad med overtøjet på under hele forestillingen og klaprede med tænderne og ustandselig slog hænder og fødder mod hinanden for at holde varmen. Det var næsten skæbnens ironi, da Mimi dør af lungebetændelse! 


\section{Nydanskerne}

Der havde allerede før krigen boet enkelte dansksindede familier i vores gade, som vi godt nok dagligt havde med at gøre, men altid havde set lidt ned på. Det drejede sig især om børnerige familier og tit om de fattigste. Det kunne man f.eks. se på børnenes tøj, undtagen når de efter sommerferien kom hjem fra Danmark. Da var de som forvandlede og lignede små prinser og prinsesser, og så sang de i den første uges tid sanglege som »Tingelingelater«; men glansen gik hurtigt af dem, og snart løb de igen i deres sædvanlige tøj. En af pigerne forblev i Danmark, for plejeforældrene havde adopteret hende. En halv snes år havde en af disse familier boet i den lille lejlighed nednunder hos os. Der kom hvert år et barn til. Senere flyttede de hen til den anden ende af gaden, hvor de fik et halvt hus at bo $i$.

En anden af disse dansksindede syntes mine forældre bedre om, for denne familie var mere »ordentlig «, og far snakkede en gang imellem med manden. Han var arbejdsløs, fordi børnene gik i dansk skole. Det kan være, at min far havde fået pålagt at bearbejde ham. Det endte i hvert fald med, at børnene blev omskolet til tysk skole - og manden fik arbejde!

En dansksindet kone i en nabogade kaldte vi »Tippenip«, for når hun skulle give hønsene foder, kaldte hun altid: "Kom tip-tip-tip, kom tip-tip-tip!« Og sådan sagde man ikke til tyske høns!

I kapitulationsdagene vejede der pludselig ved mange huse små danske flag. De skulle vel gøre englænderne opmærksomme på, at der ikke boede tyskere dér. Fra det tidspunkt optrådte de dansksindede mere selvbevidst. De tysksindede havde meget travlt med at sprætte den hvide cirkel med det sorte hagekors af naziflaget; men bagefter kunne man selvfølgelig tydeligt se, hvor den havde siddet. Disse flag var der ikke længere brug for. Senere, da der var mangel på stof, kunne de sys om til beklædning, især nederdele til pigerne.

Da flygtningene strømmede ind i landsdelen som en sand syndflod, blev flere og flere af os klar over, at vi nok havde mere tilfælles med danskerne end med vore såkaldte landsmænd, og at disse "fremmede« betød en fare for hjemstavnens egenart. Hvis man ville forhindre dette og undgå at dele det slagne tyske folks nød og elendighed, så fandtes der kun én udvej: Væk fra Tyskland! Sympatien for det danske steg og steg. Nu blev man sig bevidst, at man egentlig aldrig havde været en rigtig tysker, men kun en »tvangspreusser«. Da det lille og førhen ganske ubetydelige danske mindretal oprettede lokalafdelinger (distrikter) af den danske forening i de forskellige bydele, stod folk i kø for at blive medlemmer. Måske hjalp også rygtet om, at man kunne få "pakker«, d.v.s. madvarer.

Men først i begyndelsen af marts 1946 fandt nogle af os drenge indenfor i 


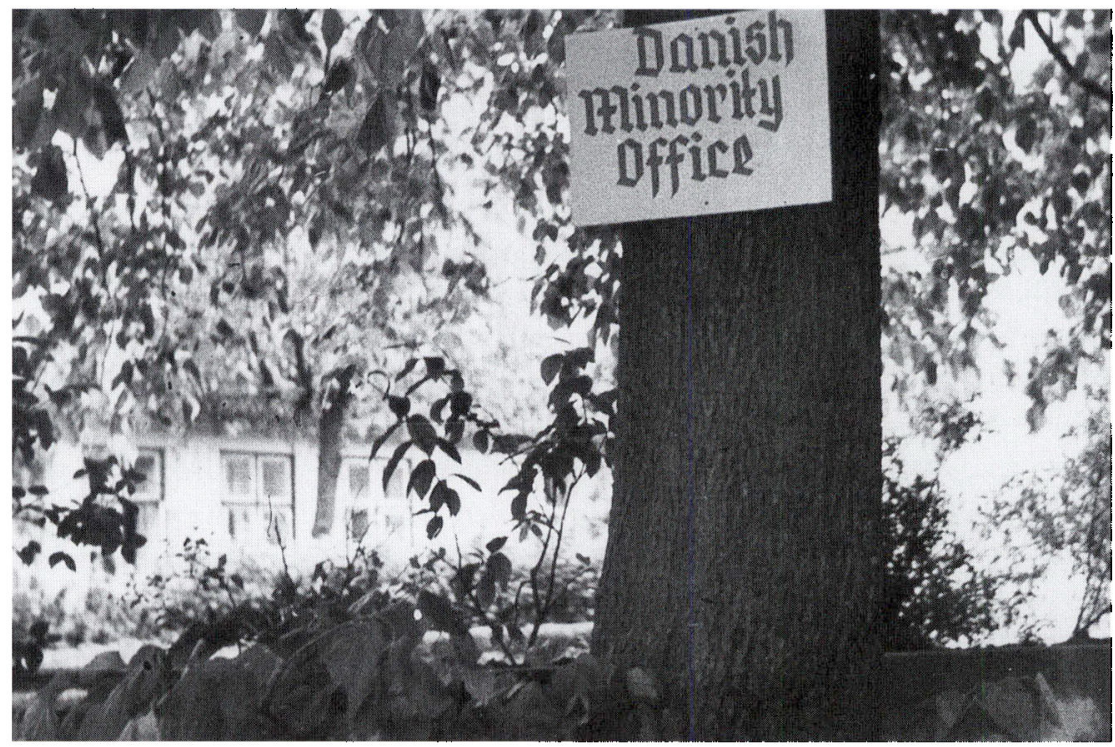

Det danske mindretal indrettede kontor i Ansgar Skolen i Slesvig. Af hensyn til den britiske besattelsesmagt blev der vist vej med et skilt på engelsk. Foto i Dansk Centralbibliotek for Sydslesvig.

Ansgar-Skolen, den danske skole i Bismarckgade. En eller anden i gaden havde fortalt, at man dér havde en ungdomsgruppe, hvor man mødtes en bestemt aften om ugen. Vi var nysgerrige, for måske var det noget for os. Da vi ankom, hilste vi på nogle unge på vores alder, og vi samledes i naturhistorielokalet. Situationen trykkede os, for dels var vi i uvante omgivelser og dels blandt fremmede mennesker; men først og fremmest hørte vi et ukendt sprog, som vi naturligvis ikke forstod et ord af og derfor heller ikke, hvad der foregik. Vi fik dog fat $i$, at deres organisation hed »spejder«, som jeg troede blev stavet med y. Det er det første danske ord, der står i min dagbog. Man gav os nogle love, som vi skulle lære udenad til næste gang; men da vi så på papiret, kunne vi ikke tyde teksten. Vi mødte et par gange; men da vi stadig væk ikke forstod deres volapyk og velsagtens også havde besvær med at lære spejderloven udenad, kom vi der ikke oftere. Jeg var dog blevet registreret som medlem i Slesvig Ungdomsforening.

Omtrent på samme tid hørte vi, at der blev arrangeret folkedans i det danske forsamlingshus "Slesvighus«. Det var lige noget for os, altså af sted! Lederne var et dansk lærerpar. Ester Lovmand stillede os op og forklarede, hvad vi skulle gøre, og Svend Lovmand spillede på violin. Mærkeligt nok holdt han ikke på buen nede ved froschen, men midt på den. Og så gik dansen. Vi 
morede os dog ikke rigtigt, da vi ikke forstod instruktionerne, der blev givet på dansk. Så også dér kom vi kun få gange.

$\mathrm{Ca}$. et års tid senere blev min familie medlem af Sydslesvigsk Forening (SSF). Om det helt og holdent var min egen beslutning, eller om jeg bare gjorde det, fordi alle andre gjorde det, kan jeg ikke sige i dag. Indmeldelsen foregik på følgende måde: Da man sikkert som i nazitiden skulle dokumentere sit tilhørsforhold til den nordiske race eller at slægten altid havde boet nord for Ejderen, tog jeg mappen med slægtstavlen under armen og gik ind på kontoret i "Slesvighus«, hvor jeg lagde den på bordet og kom frem med mit ærinde. Kontormedhjælperen kikkede flygtigt $\mathrm{i}$ den og rakte den tilbage med en blanket i A-5 format til hvert familiemedlem. Så vidt jeg husker, havde den dansk tekst på den ene side og tysk på den anden, så der har ikke været vanskeligheder med at udfylde den. Dagen efter afleverede jeg blanketterne, og dermed var vi blevet »danskere«. I tyskernes øjne »flæskedanskere«.

Det næste skridt skete i efteråret 1947, hvor jeg deltog i danskundervisnin-

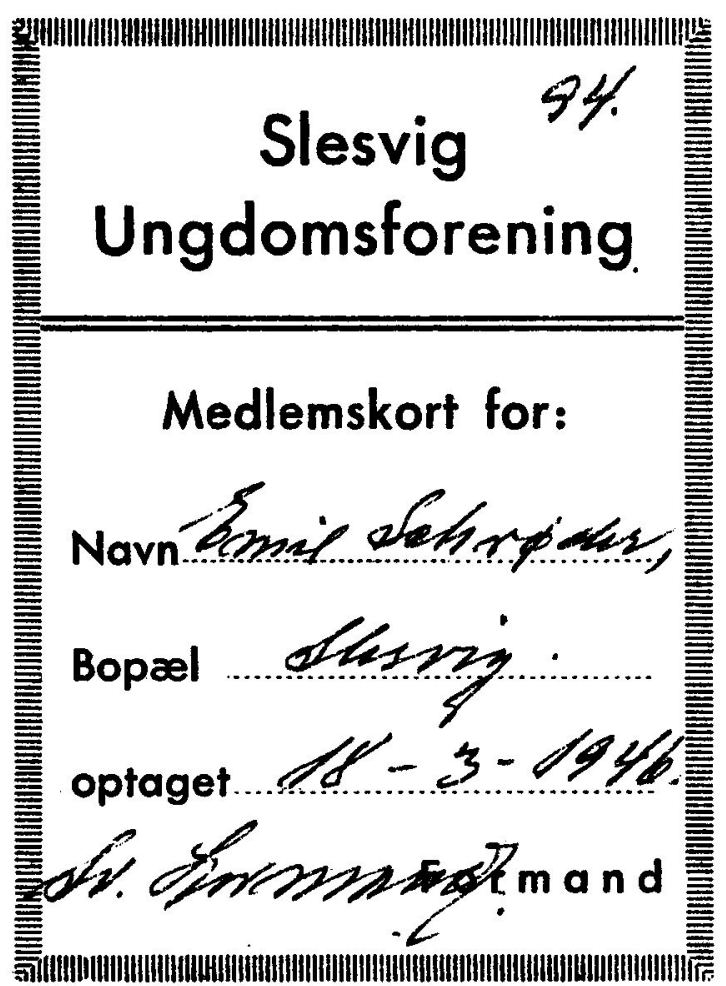

Medlemskort i Slesvig Ungdomsforening udstedt 18. marts 1946. Foreningsarkiv F 117-4. 
gen, og nu holdt jeg ud og mødte trofast to gange om ugen. Jeg lærte dog ikke nok til, at jeg kunne forstå og tale dansk.

Enkelte gange kom jeg i en kreds af jævnaldrende, hvor vi diskuterede oprettelse af en modstandsbevægelse, der bl.a. skulle have til formål at fjerne tyske mindesmærker og overklæbe gadeskilte med danske navne. Det blev dog ved snakken.

\section{På dansk håndværkerskole}

En af mine kammerater, der havde gået i dansk skole, fortalte mig, at det var muligt at komme på håndværkerskole $\mathrm{i}$ Danmark. Det må have været $\mathrm{i}$ begyndelsen af 1948. Han vidste også, at vi skulle henvende os til Jørgen Andersen, der var formand for den danske håndværkerforening i Slesvig by og som var ingeniør ved byens kraftværk. Vi opsøgte ham på hans kontor. Det var han nu ikke særlig glad for; men han havde dog nogle skemaer liggende. Han talte dansk med kammeraten, og jeg forstod ikke, hvad de talte om. Efter at have afleveret skemaerne, der skulle udfyldes på dansk, gik der lang tid; men endelig kom der besked $\mathrm{om}$, at vi skulle tage til håndværkerforeningens kontor i Storegade i Flensborg. Der manglede stadig mange formaliteter, bl.a. en lægeundersøgelse, og militærregeringen skulle ansøges om et pas.

I begyndelsen af oktober 1948 samledes en stor flok unge sydslesvigere ved Duborgkasernen i Flensborg. Dansk Kørselstjeneste i Sydslesvig skulle herfra køre os til Håndværkerskolen i Sønderborg.

Det første måltid blev uforglemmeligt. Med forbløffelse så vi de veldækkede borde, hvor der var rigeligt med rug- og franskbrød, ost, marmelade, havregryn og mælk. Vi spiste og spiste, og $\mathrm{i}$ en håndevending var skålene tomme; men lige så hurtigt kom pigerne ind med nye, der omgående blev tømt. Det så ikke ud til, at der overhovedet var bund i os; men omsider orkede vi dog ikke at spise mere.

Dagene gik med danskundervisning, som jeg ikke fattede ret meget af, hvorfor jeg hele tiden sad i nærheden af en, der kunne fortælle mig, hvad jeg skulle gøre. Om eftermiddagen gik vi en del ture for at se på byens og omegnens seværdigheder. Normalt skulle vi være hjemme kl. 22, for da blev døren låst; men en af aftenerne kom vi dog ud til dans og opsøgte »Katharinenlund « lidt uden for byen. Vi havde glædet os til at lære nogle søde piger at kende, men blev slemt skuffet. De så ganske almindelige ud og dansede ærlig talt dårligt. Aftenen kostede den formidable sum af $4 \mathrm{kr}$., hvilket jeg mente var meget, da vi kun havde fået $10 \mathrm{kr}$. i lommepenge nogle dage forinden. Resten brugte jeg, da vi havde fået rationeringsmærker, til at købe chokolade for. Vi havde un- 
drende lagt mærke til, at der taltes tysk i danselokalet. På en af turene gennem byen havde vi ligeledes bemærket, at der stod nogle mænd og talte tysk med hinanden; men da vi nærmede os, slog de over til dansk.

Efter en måneds tid blev vi fordelt på forskellige håndværkerskoler. Sammen med fire kammerater kom jeg til Skals ved Viborg. Det var en skole for tømrere og murere. $\mathrm{Og}$ nu begyndte fem dejlige måneder. Der gik flere uger, før jeg forstod det meste af, hvad der blev sagt; men for hver dag gik det fremad, og snart kunne jeg også tale sproget så nogenlunde. Det kneb dog stadig lidt med forståelsen, især når kammeraterne talte dialekt, og når de ovenikøbet talte med pibe i munden, så var det helt galt. Bedst forstod jeg forstander Bruun og hans kone.

Vi var kommet $\mathrm{i}$ vores »bedste tøj«, men lignede nok mest fugleskræmsler. Bruun skaffede os noget brugt fra flinke mennesker $i$ byen, og meget af det var så godt som nyt. En manufakturhandler forærede mig således en dejlig varm frakke, og senere, da vi fik vores månedspenge, kunne vi endog købe et sæt tøj. Nu lignede vi kammeraterne, i hvert fald i det ydre.

Livet på skolen var præget af højskoleånden, og det tiltalte mig i høj grad. Jeg kunne godt lide morgen-og aftensangen, og i sangtimen lærte jeg mange danske sange og salmer og kom til at holde oprigtigt af dem. Bruuns yndlingssalme hed »Nu skal det åbenbares«. Sangtimerne foregik ofte i forstanderens dagligstue, og vi kunne stå mange minutter i kø foran døren for at komme ind, og det var ikke bare for at få en blød lænestol at sidde $i$; men det var simpelthen hyggeligt. Selvfølgelig fik vi også de nødvendige faglige kundskaber, og foredragene udvidede vores horisont.

Julen nærmede sig. Da jeg ikke havde råd til at rejse hjem, inviterede Jens, en af eleverne, mig til at tilbringe ferien hjemme hos sine forældre. De boede i Mou, og her oplevede jeg for første gang en dansk jul med gåsesteg og æblekage, og hvad der ellers hører julen til. Vi dansede dog ikke omkring juletræet og sang heller ingen julesange, da de nok ikke kunne synge. Det blev en dejlig ferie, hvor jeg ovenikøbet fik lov til at følges med broderen, der også var murer, og således tjene lidt lommepenge.

Tiden gik hurtigt, og snart måtte vi atter tage hjem. Da vi nærmede os grænsen, rullede vi vinduet ned og prøvede at ramme grænsestenen med en flaske. Ved kontrollen på banegården i Flensborg spurgte den tyske tolder, hvad jeg havde i bagagen, og på dansk svarede jeg: »Øl«. Det drejede sig om en påskebryg til min far. Han forstod det som »Öß (olie) og ville se flasken; men da jeg tog den frem, udbrød han: »Ach so, Bier!

Desværre skrev jeg ikke dagbog fra 6. maj 1948-25. april 1949. Jeg begyndte altså først igen, da jeg var kommet hjem og skrev så om opholdet i Skals. Det er skrevet på dansk; men de efterfølgende notater er atter på tysk. 


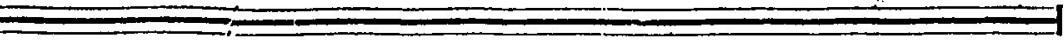

\section{DET DANSKE \\ AARSMÖDE 1949}

for Gottorp Amt og Rensborg Nörreame

Lớr dag, den 11. Juni 1949, Kl. 20

Aftenforanstaltninger Rensborg ".Det Tyske Hus": Bŭdelsdorf .Spiczkrug": "S leavig ..GroBer Baumhof". ..Slesvighus". ..Friedrichsberg": Frederikstad .Den Danske Skole": Ka p pel ..Den Danske Skole" Sonderbrarup ..Wendts Tivoli"

Sóndag, den 12. Juni $19 \$ 9$

\section{Stort Friluftsmöde}

i Slesvig, "Schützenkoppel"

Til Opmarchen samles Kl. 13 ved „Kreisbahnhof" og „Bahnhof Friedrichsberg" " March gennem Byen til Festpladsen med Orkester

$$
\begin{gathered}
\text { Frilufts-Moders Program paa Bagsiden } \\
\text { Stor B Örnefest! } \\
\text { med mange } \begin{array}{c}
\text { Forlystelser og Konkurrence, med } \\
\text { Praemiefordeling }
\end{array}
\end{gathered}
$$

Programmet berettiger til Deltagelse Lórdag-Afren og Friluftsmódet og gracis Beģyttelse af vore Transportmidler.

$$
\text { Programmet oster DM } 0.25
$$

Indbydelse til årsmøde $i$ Slesvig 1949. 


\section{Hjemme i Slesvig}

En af kammeraterne havde inviteret mig til at overnatte i Flensborg. Vi lå i forældrenes dobbeltseng, og midt om natten vågnede jeg ved, at noget blødt puslede ved mine fødder. Forskrækket vækkede jeg ham, og med forbløffelse så vi, at deres hund havde fået hvalpe i fodenden af sengen!

Næste dag fortsatte jeg rejsen til Slesvig, og der var stor gensynsglæde. Min far havde tiltusket sig en motorcykel, som jeg straks skulle have en tur på.

Min mester havde ikke arbejde til mig; men onkel Max, der var tømrermester, tilbød mig noget. Min far var nu hos ham som sleeping-partner og stod for murerafdelingen. På arbejdsformidlingen lykkedes det omsider at få tilladelse, og så kunne jeg begynde. På min 21 års-fødselsdag kørte far og jeg til Vester-Åkeby i Angel, hvor mine bedsteforældre på mødrene side boede. Dem har jeg kun set tre gange i mit liv.

Friluftsmødet i Slesvig i anledningen af årsmødet 1949 samlede over 18000 mennesker. Vejret var strålende. Jeg længtes efter at tale og høre dansk, selv om jeg vedblev med at skrive på tysk $\mathrm{i}$ dagbogen indtil oktober samme år, og fra dette tidspunkt gik jeg helt over til det danske.

Den følgende måned bestod jeg min svendeprøve med "godt«. Mesteren var lidt utilfreds med karakteren for den praktiske del. Grunden var, at jeg havde hjulpet sidemanden, der havde vanskeligheder med at lægge sine sten rigtigt, og derfor nåede jeg ikke selv at blive færdig til tiden.

Gennem nogle måneder var en snes unge på min alder kommet sammen for at oprette et tysk trommer- og piberkorps. De fleste af os tilhørte mindretallet, og vi ønskede ikke at spille preussiske marcher og slet ikke slesvigholstenernes oprørssang "Schleswig-Holstein meerumschlungen«. Vores »uniform« bestod af blå bukser og hvid skjorte. Vi øvede flittigt, og en ældre mand instruerede os hver søndag morgen i skoven.

Der havde været møde i »Slesvighus«, hvor statskonsulent Toftdal-Møller var til stede, og hvor han meddelte mig, at man havde imødekommet min ansøgning om et nyt ophold på en håndværkerskole. I denne tid gik jeg nogle gange til ungdomsforeningens møder, f.eks. til skak, folkedans og diskussionsaftener.

\section{Atter i Danmark}

Den 13. oktober 1949 mødtes vi sydslesvigere, der skulle på håndværkerskole, i Flensborg for at blive kørt til Sønderborg. Alt var anderledes denne gang. Nu forstod jeg, hvad der blev sagt; men på en måde var det ikke så spændende 

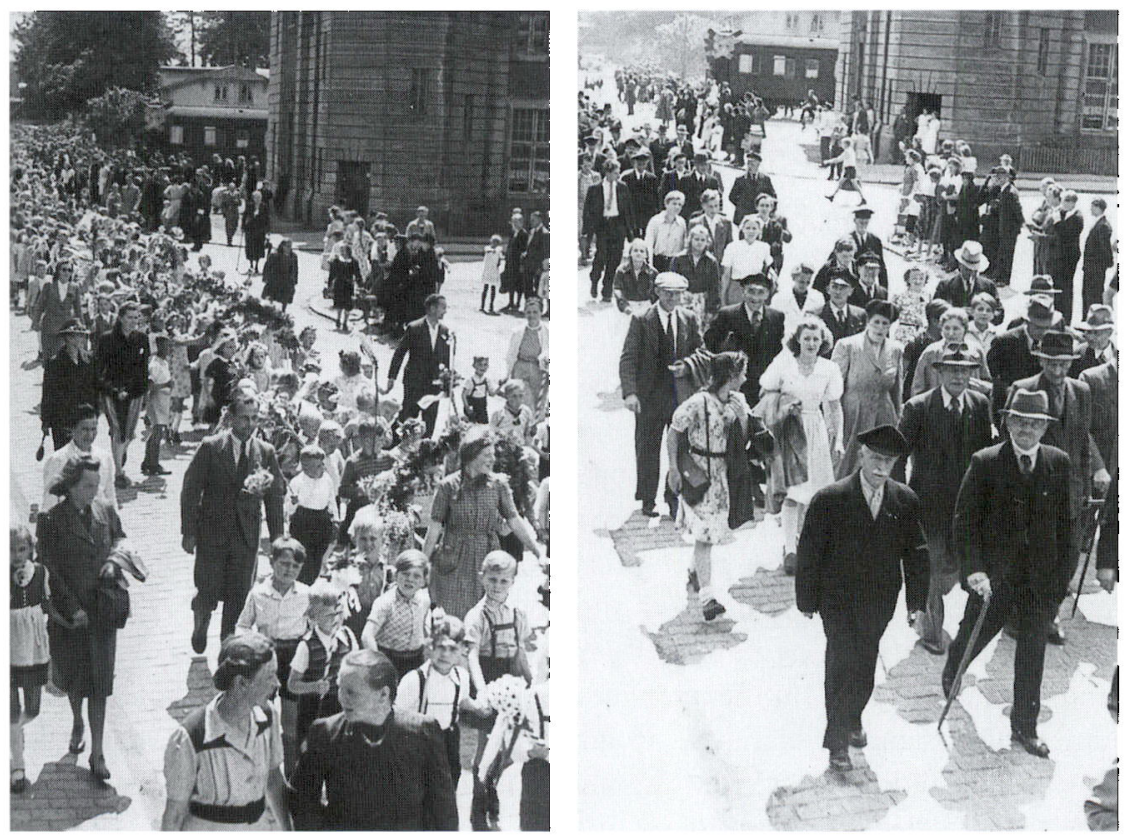

I forbindelse med årsmodet i Slesvig 1949 var der stor bornefest og optog. Foto i Dansk Centralbibliotek for Sydslesvig.

som året før. Dagene gik med for megen lediggang, fritiden vidste jeg ikke at bruge til noget fornuftigt. Med spænding ventede vi på afgørelsen om, hvilken skole vi skulle på. Det blev en stor skuffelse, for jeg skulle atter til Skals. Ikke at jeg var ked af at komme derhen igen; men jeg havde ansøgt om at få et mesterkursus, som ikke kunne tages dér. Dog viste det sig efter min ankomst, at min frygt for at gentage forrige års pensum var ubegrundet, for jeg fik hele tiden opgaver, der tog sigte på mine fremtidige ønsker.

På kurset var vi fire sydslesvigere, og som året før var to af os fra Slesvig by. Denne gang rejste de to hjem til Sydslesvig på juleferie. Vi andre blev på skolen. Juleaftensdag pyntede vi træet og kom til at opleve en uforglemmelig dansk jul. Anden juledag så vi den pragtfulde film »De røde sko«, lavet over et af H.C. Andersens eventyr.

Inden året 1949 randt ud, nedkom fru Bruun med en søn. Nytårsaften skålede vi for hende og skød fyrværkeri af, som det sig hør og bør. Bagefter gik jeg til bal på kroen.

Bruun var dirigent for den stedlige sangforening, og da der manglede tenorer, bad han nogle af os om at være med. Hele vinteren øvede vi en gang om ugen på kroen. 
I vinterens løb tog vi bl.a. til en Chopinkoncert i Viborghallen og som året før til Dollerupbakkerne. Vinterens højdepunkt var rejsen til København. Vi sejlede med "Ydun« fra Randers, og det var forbløffende at se, hvor smal fjorden var, og skibets bølger skyllede ind over de lave enge. Desværre var vejret gråt, da vi stod ind gennem Øresund. I København aflagde vi den første dag besøg på Burmeister \& Wain og Teknologisk Institut. Om aftenen så vi balletterne »Auroras bryllup«, »Den skønne Donau« og »Petruska« på Det kongelige Teater. Jeg syntes bedst om den sidste; men den faldt langtfra i kammeraternes smag, og nogle af dem havde svært ved at holde sig vågen efter den anstrengende dag.

Næste morgen stod Radiohuset på programmet. En af personalet, der viste rundt, skyndte hele tiden på os med sit »tempo, tempo!«. Det næste mål var Christiansborg, hvor vi så på Rigsdagen og De kongelige Repræsentationslokaler. Vi skulle selvfølgelig også til vagtafløsningen på Amalienborg Slotsplads kl. 12. Fanemarchen og de farverige uniformer imponerede. Efter middagen stod Glyptoteket for tur. Senere ville nogle af os til »Palladium« for at se en film, mens resten, deriblandt jeg, tog til Grundtvigskirken. Samme aften sejlede vi tilbage til Randers. Vejret var smukt. København og Kronborg præsenterede sig fra deres kønneste side.

Nogle dage efter hjemkomsten cyklede en seks-syv stykker af os i det herligste solskinsvejr og gennem den mest pragtfulde natur til Tjele for at se den herregård, hvor Marie Grubbe havde levet.

Da kammeraterne havde aflagt svendeprøve, rejste de hjem, mens vi sydslesvigere endnu blev en fjorten dages tid og arbejdede $i$ haven. Vi deltog $i$ »lillebrors« dåb og den efterfølgende fest, hvor Bruun holdt en varm og inderlig tale for sin kone. En af dagene tog jeg til kriminalpolitiet i Hobro for at få en arbejdstilladelse; men det var forgæves.

Den 14. april 1950 skulle vi forlade landet. Udadtil syntes mine kammerater og jeg at være i godt humør; men inderst inde var vi dybt bedrøvede over at skulle forlade dette dejlige sted, hvor vi havde lært meget og følt os hjemme. Måske ville vi aldrig komme der mere og gense vore venner.

\section{»Dansk mestersvend « i Sydslesvig}

Snart arbejdede jeg igen som murer, og i min fritid deltog jeg hovedsagelig $\mathrm{i}$ ungdomsforeningens arrangementer. Årsmødet samlede færre mennesker end året før, og der rådede ikke den samme stemning som tidligere. Hidtil havde jeg haft et noget distanceret forhold til religion. Jeg havde således aldrig været til en gudstjeneste på min hjemegn; men i Skals havde jeg været i kirke, og da 
der nu i forbindelse med årsmødet fandt en festgudstjeneste sted i Slotskirken, benyttede jeg lejligheden. Sydslesvigsk Forening gav også medlemmerne mange fine kulturelle tilbud, f.eks. spillede Det kongelige Teater "Foran spejlet « med Karin Nellemose og Ebbe Rode og bagefter enakteren »Den kongelige gæst«. En anden gang opførte Odense Teater »Gulddåsen« med Henrik Malberg som Falsmål.

Også tyskernes aktiviteter kunne lokke. FDJ (Freie Deutsche Jugend), en kommunistisk ungdomsorganisation, indbød til et gratis pinsestævne i Berlin; men vi faldt dog ikke for fristelsen. Vi gik nogle gange til tyske valgmøder, bedst husker jeg kommunisternes, for deres stedlige leder var en fremragende taler.

Men det var dog især de danske forsamlinger, jeg gik til. Der var ofte tale om protestmøder om flygtningeproblemet. Selvfølgelig ønskede vi sydslesvigere at bestemme $\mathrm{i}$ vor hjemstavn og måtte frygte en yderligere fortyskning. Helst ville vi "stride landet hjem igen til Danmark« ("Vi er Sønderjyllands ungdom« af Jørgen Jessen). Flere gange sad jeg ved siden af gymnasielærer Hansen fra Domskolen i Slesvig. Engang, efter at vi havde sunget »Det haver så nyligen regnet«, hvor der står i sidste vers »det har slet ingen hast for dem, som tror«, sagde han henvendt til mig: »Det haster i allerhøjeste grad!« Han tænkte naturligvis på en genforening med Danmark.

I midten af juni 1950 kom Bruun og en kammerat fra Skals og hans kæreste cyklende for at besøge os slesvigere. Selvfølgelig skulle vi se på Gottorp Slot, Johannesklostret, domkirken, Valdemarsmuren og Hedeby. Vi var overordentlig glade for besøget.

Sankt Hans-aften tændte ungdomsforeningen bål på stranden ved Hedeby Kro, og Ansgar-Skolens leder Svend Johannsen holdt en ualmindelig fin båltale på vers. Aftenen sluttede med dans. Næste nat kørte vi ud til landsbyerne $i$ den vestlige del af Slesvig Amt for at sætte valgplakater op. Ved 4-tiden var vi hjemme igen.

Engang tog jeg en flygtningepige med til en distriksforsamling, hvor en norsk jente i nationaldragt spillede Schumann, Schubert og naturligvis Grieg. Da vi gik hjem, sagde jeg lidt bittert til pigen, at nu havde hun deltaget $i$ et møde hos »landsforræderne«, som tyskerne kaldte os.

Min gamle læremester onkel Hermann døde sidst $\mathrm{i}$ juni måned. Han havde altid været venlig mod mig. Aftenen på hans dødsdag opsøgte jeg formanden for håndværkerforeningen i Slesvig Herbert Maas, der tilbød at give mig gratis undervisning i statik. Jeg kom så hos ham en gang om ugen $\mathrm{i}$ mere end et halvt års tid. Efter nogen tid opdagede han mine manglende matematikkundskaber, og dette sinkede min forståelse af opgaverne; men jeg gjorde alligevel ret gode fremskridt. 


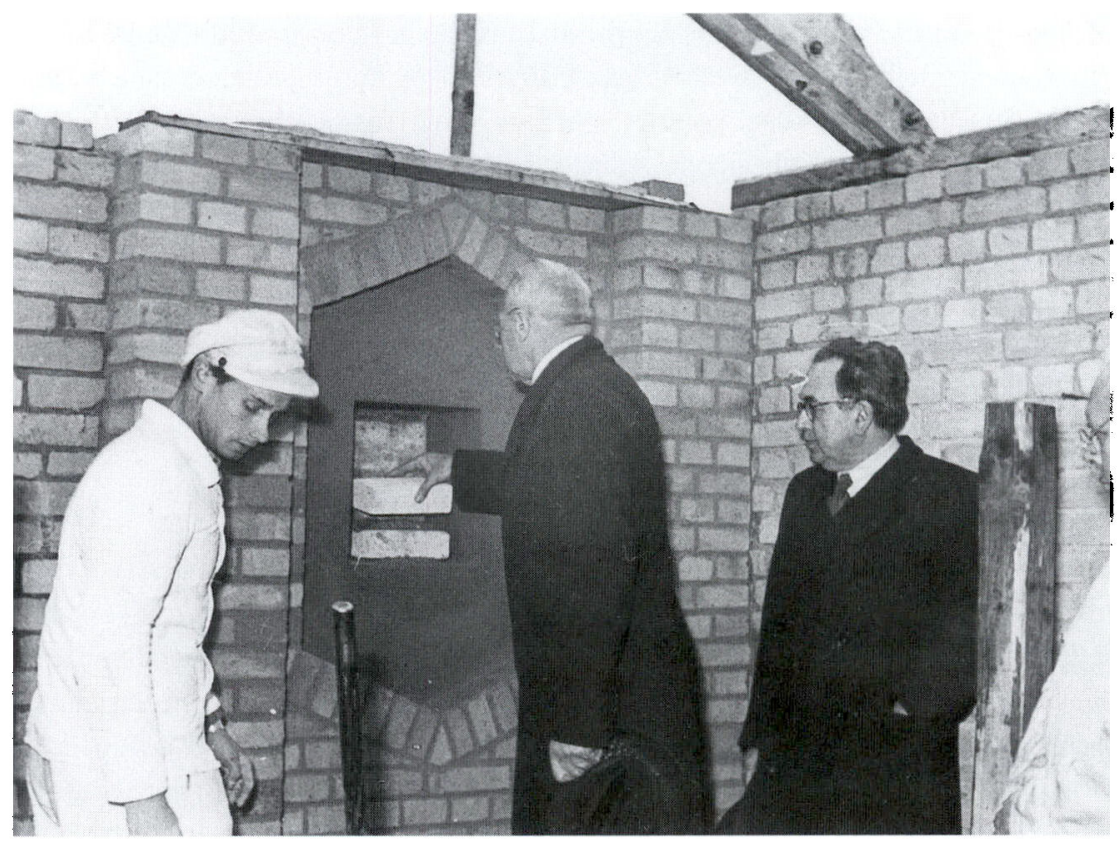

Grundstensnedlaggelse til menighedshuset på Frederiksherg 1950. Fra venstre Emil Schroder, biskop Noack og provst Nedermark. Foto i ADCB personarkiv P 318.

Den 9.juli 1950 var der landdagsvalg. Det blev atter til tilbagegang i det danske stemmetal. Hvad var årsagen dertil? Var sydslesvigerne alligevel tyskere af sind? Jeg kunne ikke tro det.

I sommerens løb fik jeg fat i en gammel kajak. Turene gik ofte til Hedebyog Selknor. Jeg havde nu fået lyst til vandet og nød at være ude i den smukke natur. Sammen med to kammerater, hvoraf den ene var snedker, byggede vi hele vinteren igennem hver for sig en kajak, idet vi benyttede den gamle kajak som model. Min båd kom til at hedde "Haab«, og de andre hed "Tro« og »Kærlighed«. I bagenden havde vi en vimpel med de slesvigske løver. Vi har sikkert været de første både i Slesvig, der fik danske navne, så vi var faktisk forløbere for "Slesvig Roklub«.

I oktober samme år skiftede jeg til firmaet Heinrich Mahrt, der var ved at bygge den danske præstegård på Frederiksberg. Indehaveren var dansksindet. Som ny mand måtte jeg byde på en flaske snaps. En læredreng blev sendt af sted efter den. Da flasken var tømt, blev der samlet ind til en ny, og resten af dagen gik med drikkeri. Arbejdsmanden, der var vores nabo, blev så fuld, at han ikke kunne ramme betonblandemaskinen med vandstrålen, da han inden fyraften skulle rense den. Nogle børn grinede højt af ham. Det blev han gal 
over og ville sprøjte på dem; men idet han trådte nogle skridt baglæns, faldt han over en grusbunke, og vandet fossede over ham. Bagefter opsøgte han nogle knejper og kom godt pløret hjem ved 20-tiden og tævede konen og plejebørnene, så de hylede og skreg. Da fik jeg dårlig samvittighed, for jeg var jo den indirekte årsag til, at de fik prygl.

I oktober kom Bruun på besøg igen. Han arbejdede på at få mig til Odense. Desværre blev planerne torpederet nogle dage senere, da der kom en opringning fra håndværkerforeningens kontor i Flensborg, hvor man meddelte mig, at jeg af to grunde ikke kunne komme til Danmark den følgende vinter: 1) jeg var endnu for ung til et mesterkursus og 2) jeg havde udtalt, at jeg havde mest lyst til at komme på teknikum; men pengene dertil kunne først bevilges året efter. Det var et hårdt slag, og hvis jeg havde vidst det noget tidligere, så havde jeg sparet sammen til bygmesterskolen i Egernførde.

Et af højdepunkterne i min tid som murer var rejsegildet på menighedshuset på Frederiksberg. Grundstensnedlæggelsen fandt sted ved samme lejlighed. Det var min opgave at sørge for, at sten og mørtel var til stede og at assistere. Derefter talte bl.a. biskop Noack. Til sidst sagde jeg som mestersvend nogle ord på dansk og tysk og udbragte et leve på håndværkernes vegne.

Den næste bygning, vi rejste, var den danske skole i Ny Bjernt, og her arbejdede vi både lørdag og søndag. Derpå fulgte Gottorp-Skolen i Slesvig, hvor vi startede den 10 . november 1950.

Den 4. december hentede Skoleforeningens byggekonsulent Agerskov mig, og vi kørte til Hatsted nord for Husum, hvor jeg skulle medvirke ved et rejsegilde på den danske skole. Det skulle afslutte Danmarks Radios udsendelse »Der rejses skoler i Sydslesvig«. Rejsegildet var et fiktivt arrangement, for der var ikke rejst spær, dog fik håndværkerne, der var til stede, en flaske snaps. Man havde desværre ikke sagt til mig, hvordan jeg skulle tale i mikrofonen, og derfor brugte jeg en stemmeføring, som om jeg stod oppe på taget. Svend Alkærsig trådte forbløffet et skridt tilbage, og teknikerne fik travlt med at skrue ned for lydstyrken!

Højskoleaftenerne foregik nu hos pastor Bundgaard i det nybyggede menighedshus på Frederiksberg. To dage efter hørte vi dér reportagen, og det var lidt ejendommeligt at høre sin egen stemme. Bundgaard gennemgik forøvrigt den aften bogen »Blad af en blomst « af Tolderlund-Hansen.

Midt i december blev jeg sagt op og måtte melde mig på arbejdsformidlingen som arbejdsløs, og to dage før jul kunne jeg hente min første understøttelse. Ved aftenskolens julefest genfortalte pastor Rommerdahl Selma Lagerløfs "Den hellige flamme« på en aldeles blændende måde.

Jeg havde spurgt Bruun i mit julebrev, om jeg kunne få lov til at komme på besøg i januar 1951. Han svarede sidst på måneden, at jeg skulle være velkom- 


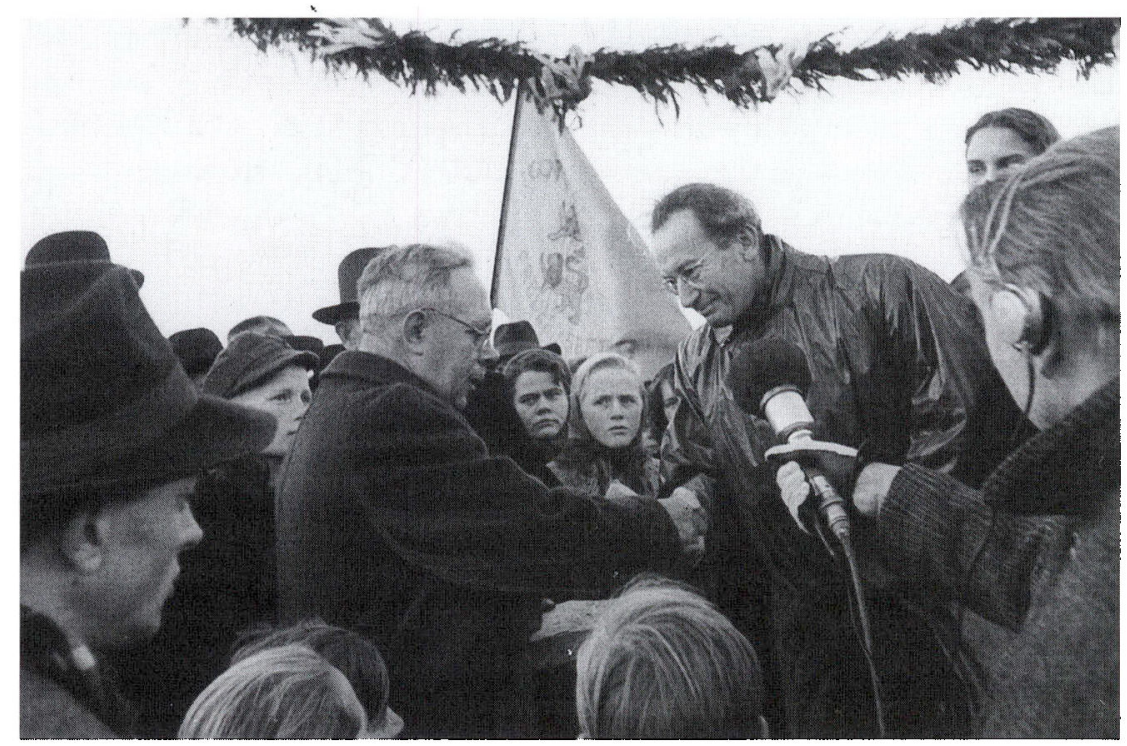

Fra grundstensnedlaggelsen til Gottorp-Skolen 1950. Rektorerne Wehlitz (t.v.) og Svend Johannsen (t.h.) hilser på hinanden. Foto i Dansk Centralbibliotek for Sydslesvig.

men. Men selv om det lykkedes mig at få et nyt pas, hvad der slet ikke var så lige til dengang, så var der alligevel så mange vanskeligheder, at rejsen ikke blev til noget.

Foreningsarbejdet startede igen i begyndelsen af det nye år. I ungdomsforeningen fortalte skoleinspektør Wehlitz om Hans Helgesen. På højskoleaftenen den 10. januar skulle jeg fortælle om H. P. Jakobsens roman "Peter Nogensen«. Den udkom på tysk i 1947 og på dansk i 1948 og belyser sindelagsskiftets historie. Jeg tror nọ, at jeg misforstod opgaven og genfortalte den. På et tidspunkt langt inde i foredraget opdagede jeg til min rædsel, at jeg havde glemt et af de væsentligste kapitler, nemlig Peter Nogensens kontakt med det danske; men det slog mig dog ikke ud. I begyndelsen havde jeg været lidt nervøs; men det fortog sig, så snart jeg var begyndt, og derefter talte jeg i halvanden time. Det var måske lovlig længe for dem, der kendte bogen, mens andre så tilsyneladende ikke behøvede at læse den. Pastor Bundgaards ros glædede mig naturligvis meget.

Aftenskolen kunne ikke fortsætte i Ansgar-Skolen, da den måtte lukke på grund af kulmangel. Først foregik undervisningen i den tyske WilhelminenSchule, men til sidst hjemme hos de forskellige lærere. Jeg gik til dansk og litteratur, og mine lærere var frk. Bredegård og Bent Skovrup. Her holdt jeg bl.a. foredrag om den tysksindede friser Uwe Jens Lornsen. 
Den 23.januar 1951 ringede frk. Bredegård på hos os for at overtale mig til at spille løjtnant Wilmer i Hostrups »Soldaterløjer«. Det mærkelige var, at jeg to år forinden havde fået tilbudt samme rolle, som jeg dengang havde afslået. Samme eftermiddag mødtes vi hos pastor Rommerdahl, og efter en sangprøve blev det konstateret, at jeg var udpræget tenor. Værre gik det ved læseprøven. Min udtalelse var ikke god nok og blev rettet hele tiden. Det gjorde mig lidt urolig. Disse vanskeligheder plagede mig nu hele tiden, også når jeg siden holdt foredrag.

På et sendemandsmøde den 17. februar 1951 blev Sydslesvigs danske Ungdomsforeningers fane indviet, og jeg slog det andet søm i. På den efterfølgende generalforsamling den 10. april $1951 \mathrm{blev}$ jeg foreslået som formand for ungdomsforeningen i Slesvig. Det sagde jeg dog nej til, da jeg måtte regne med et nyt skoleophold i Danmark.

\section{Tiden derefter}

Af afgørende betydning for min videre udvikling blev »frk. Emilie« alias den danske lærer Edith Uttenthal Jensen, der var min kæreste i "Soldaterløjer«. Vi lærte hinanden at kende, og det ændrede mine fremtidsplaner. Jeg fik lyst til at fortsætte den læreruddannelse, som var blevet afbrudt i 1945. Og senere blev hun min kone.

Den 2. juli 1951 cyklede jeg til Jaruplund Højskole for at tale med forstander Jørgen Jessen. Han rådede mig til at fortsætte mine studier på et tysk seminarium. Derpå cyklede jeg videre til skoleforeningens kontor på Duborg-skolen, hvor jeg udfyldte nogle papirer. Nogle dage senere opsøgte daværende viceskoledirektør Hans Meng mig på min arbejdsplads. Også han var interesseret i, at jeg fik tysk eksamen, for der manglede tysklærere. Alligevel endte det med, at jeg kom på dansk seminarium. Men forinden måtte jeg have et højskoleophold. Det blev Antvorskov Højskole, og derpå fulgte studieårene på Jonstrup Statsseminarium.

Efter lærereksamen i 1957 blev jeg skoleleder for den danske skole i Vyk på Før. Fra 1964-1974 var jeg ansat ved Bække Folke-og Realskole, for derefter atter at tage tilbage til Sydslesvig. Skæbnen ville det sådan, at jeg fik mit sidste embede på Gottorp-Skolen, som jeg selv havde været med til at bygge.

Fra at være tysksindet var jeg blevet dansk, og som et synligt bevis derpå fik mine børn og jeg den 17. december 1965 dansk indfødsret. I dette dokument er mit efternavn stavet med dansk ø!

Selvfølgelig kan man stadigvæk høre på mit sprog, at jeg er født i Sydslesvig. 
Om udgivelsen

Ovenstående erindringsartikel er en let revideret $\mathrm{og}$ forkortet gengivelse af originalmanuskriptet, som findes i Emil Schrøders privatarkiv i Arkivet ved Dansk Centralbibliotek for Sydslesvig (P 318).

Se i øvrigt:

Emil Schrøder: Mein Jahr 1945, i: Schleswig in der Nachkriegszeit. Zeitzeugenberichte 1. Udgivet af Gesprächskreis Erzählte Geschichte. Schleswig 1994, s. 62-68.

Emil Schrøder: Min far, en nordisk orienteret slesviger I-III, kronikker i Flensborg Avis 1., 3. og 5. juli 1995. 